\begin{tabular}{l|l|l} 
Jurnal Eksplorasi Akuntansi & $\begin{array}{l}\text { ISSN : 2656-3649 (Online) } \\
\text { Vol. 2, No 3, Seri B, Agustus 2020, Hal 3085-3106:/jea.ppj.unp.ac.id/index.php/jea/issue/view/26 }\end{array}$
\end{tabular}

\title{
PENGARUH KEKAYAAN DAERAH DAN BELANJA MODAL TERHADAP KINERJA PENYELENGGARAAN PEMERINTAH DAERAH: PENGUJIAN KOMPLEKSITAS PEMERINTAH SEBAGAI VARIABEL MODERASI (Studi Empiris Pada Pemerintahan Kabupaten/Kota Provinsi Sumatra Barat Tahun 2013 - 2017)
}

\author{
Megawati Sukarni Putri ${ }^{1}$, Vita Fitria Sari ${ }^{2}$ \\ ${ }^{1}$ Alumni Juruan Akuntansi Fakultas Ekonomi, Universitas Negeri Padang \\ ${ }^{2}$ Jurusan Akuntansi Fakultas Ekonomi, Universitas Negeri Padang \\ *Korespodensi: megawatisukarniputri@gmail.com
}

Abstract: This study aims to examine the effect of regional wealth and capital expenditure on the performance of local government administration, and to see whether government complexity will affect the relationship betwen regional wealth and capital expenditure on the perfomance of local government administration. Population in this study were districts/cities in West Sumatera Province in 2013-2017. The analytical tool used in this study is moderate regression analysis. The results of this study indicate that regional wealth doesn't affect the performance of local government administration, and capital expenditure negatively affects the performance of local government administration. Government complexity doesn't moderate the relationship between regional wealth and capital expenditure on the performance of local government administration. The results of this study also show that complexity of the government weakens the relationship between regional wealth and capital expenditure on the performance of local government administration.

Keywords: local government administration, regional wealth, capital expenditure, and government complexity

How to cite (APA $6^{\text {th }}$ style):

Putri, M. S., \& Sari, V. F. (2020). Pengaruh Kekayaan Daerah dan Belanja Modal Terhadap Kinerja Penyelenggaraan Pemerintah Daerah: Pengujian Kompleksitas Pemerintah Sebagai Variabel Moderasi (Studi Empiris Pada Pemerintahan Kabupaten/Kota Provinsi Sumatera Barat Tahun 2013-2017). Jurnal Eksplorasi Akuntansi, 2(3), Seri B, 3085-3106.

\section{PENDAHULUAN}

Perimbangan keuangan antara pemerintah pusat dan pemerintah daerah menurut UndangUndang Nomor 33 Tahun 2004 adalah suatu sistem pembagian keuangan yang adil, profesional, demokratis, transparan dan efisien dalam rangka pendanaan penyelenggaraan desentralisasi dengan mempertimbangkan potensi, kodisi, dan kebutuhan daerah serta besaran pendanaan penyelenggaraan desentralisasi dan tugas pembantuan. Desentralisasi adalah penyerahan 
wewenang dari pemerintahan pusat ke pemerintahan daerah otonom untuk mengatur dan mengurus urusan pemerintahan daerahnya sendiri dalam sistem Negara Kesatuan Republik Indonesia. Desentralisasi fiskal memungkinkan terjadinya peningkatan pelayanan di bermacammacam sektor terutama sektor publik. Pemerintahan pusat selain memberikan wewenang kepada pemerintahan daerah untuk mengatur dan mengurus daerahnya sendiri juga memberikan kewajiban kepada pemerintah daerah untuk memberikan laporan penyelenggaraan pemerintah daerah (LPPD) kepada pemerintahan pusat.

Laporan penyelenggaraan pemerintah daerah (LPPD) merupakan bentuk laporan pertanggung jawaban penyelenggaraan pemerintahan daerah kepada pemerintahan pusat, serta bentuk pertanggung jawaban kinerja tata kelola pemerintah daerah kepada masyarakat. UndangUndang Nomor 32 Tahun 2014 tentang Pemerintahan Daerah menjelaskan bahwa LPPD berisikan informasi yang akurat dan memadai mengenai penyelenggaraan pemerintahan daerah selama satu tahun anggaran. LPPD mencangkup informasi yang bersumber dari Rencana Kerja Pemerintah Daerah (RKPD) yang dilaksanakan oleh suatu pemerintah daerah (Sedyaningsih dan Zaky, 2013). Kepala daerah di wajibkan untuk menyerahkan LPPD kepada pemerintah pusat, agar pemerintah pusat dapat mengetahui pengelolaan serta pertanggung jawaban kinerja pemerintah daerah tersebut. Penyusunan LPPD menjadi suatu hal yang penting karena LPPD berisikan suatu pencapaian kinerja pemerintah daerah dan pelaksanaan tugas pembantuan yang telah dilaksanakan selama satu tahun anggaran. LPPD yang dibuat oleh pemerintah daerah dapat dijadikan sebagai suatu bahan evaluasi untuk keperluan pembinaan terhadap pemerintahan daerah tersebut (Usman dan Misra, 2019).

Untuk mengukur kinerja pemerintah daaerah perlu diadakannya evaluasi kinerja penyelenggaraan pemerintah daerah (EKPPD). Dengan diadakannya evaluasi kinerja penyelenggaraan pemerintah daerah, pemerintahan pusat bisa mengetahui sejauh mana keberhasilan penyelenggaraan pemerintah daerah dalam mengelola daerahnya. Evaluasi Kinerja Penyelenggaraan Pemerintah Daerah (EKPPD) merupakan proses penilaian kinerja pemerintah daerah, penyelenggaraan otonomi daerah dan aspek-aspek penyelenggaraan pemerintahan daerah yang diatur dalam Peraturan Menteri dalam Negeri Nomor 73 Tahun 2009. Evaluasi kinerja penyelenggaraan pemerintah daerah (EKPPD) menggunakan laporan penyelenggaraan pemerintahan daerah (LPPD) sebagai bahan acuan utama dalam melakukan evaluasi. Hasil dari EKPPD berisikan laporan hasil evaluasi peningkatan kinerja penyelenggaraan pemerintah daerah dan digunakan oleh pemerintah pusat sebagai dasar dalam melakukan pembinaan, pengawasan, dan kebijakan pemerintahan untuk menyelenggarakan otonomi daerah atau pembentukan, penghapusan ataupun penggabungan daerah otonom (Tobu, 2018).

Pada tahun 2017 provinsi Sumatera Barat mengalami penurunan peringkat prestasi EKPPD yang cukup signifkan yaitu dari peringkat 6 pada tahun 2016 menjadi peringkat 15 di tahun 2017. Yang mana pada tahun 2017 dari 19 kabupaten/kota di provinsi Sumatera Barat hanya terdapat 5 kabupaten/kota yang mengalami peningkatan kinerja penyelenggaraan pemerintah yaitu Kota Padang, Kota Padang Panjang, Kabupaten Dharmasraya, Kabupaten Kepulauan Mentawai dan Kabupaten Solok Selatan. Penurunan peringkat ini terjadi karena adanya delapan indikator kinerja kunci (IKK) yang mengalami penurunan yaitu, jumlah penanaman modal dalam negeri (PMDN), jumlah ekspor, serapan APBD dan seterusnya. Selain itu turunnya peringkat kinerja penyelenggaraan pemerintah di nasional juga di sebabkan karena data agregasi dari pemerintah daerah kabupaten/kota di provinsi Sumatera Barat (Dani, 2019).

Untuk meningkatkan kinerja pemerintah daerah maka pemerintah daerah harus lebih meningkatkan pelayanan, sarana dan prasarana publik dan pembangunan di daerahnya. Salah 
satu cara agar pelayanan publik meningkat pemerintah daerah dapat memanfaatkan sumber kekayaan daerahnya. Tingkat kekayaan daerah adalah semua sumber penerimaan daerah yang digunakan untuk kesejahteraan masyarakat (Tobu, 2018). Siddi (2016), tingkat kekayaan daerah merupakan suatu bentuk sumber daya yang dimiliki oleh pemerintahan daerah yang digunakan pemerintah untuk melaksanakan fungsi pelayanan kepada masyarakat. Kekayaan daerah berbanding lurus dengan tingkat kepedulian yang dimiliki masyarakat kepada pemerintahan daerah. Sehingga semakin besar kekayaan daerah maka semakin besar pula kepedulian masyarakat terhadap pengelolaan kekayaan daerah tersebut oleh pemerintah (Afriansyah, 2013). Kekayaan daerah dapat diukur dengan menggunakan total aset yang dimiliki oleh daerah (Pratama et al, 2015).

Peraturan Pemerintah Nomor 71 Tahun 2010 tentang Standar Akuntansi Pemerintahan Berbasis Akrual, Pernyataan Nomor 01 tentang Penyajian Laporan Keuangan, mendefinisikan aset adalah sumber daya ekonomi yang dikuasai atau dimiliki pemerintah sebagai akibat dari peristiwa masa lalu dan dari masa manfaat ekonomi dan sosial di masa depan yang diharapkan dapat di peroleh baik oleh pemerintah ataupun masyarakat, dan dapat diukur dalam satuan uang, termasuk sumber daya non keuangan yang diperlukan untuk menyediakan jasa bagi masyarakat umum dan sumber daya yang dipelihara berdasarkan alasan sejarah dan budaya. Aset juga merupakan sumber daya yang dimiliki oleh pemerintah yang bisa memberikan dampak pada kinerja pemerintah dalam melakukan pelayanan kepada masyarakat.

Kekayaan daerah yang dimiliki oleh suatu daerah harus dimanfaatkan dengan baik oleh daerah untuk meningkatkan pelayanan, sarana dan prasarana publik. Dalam memanfaatkan kekayaan daerah harus diperhatikan juga kegunaan dari kekayaan daerah tersebut, agar kekayaan daerah bisa dimanfaatkan sesuai dengan kepentingan publik. Semakin kompleks suatu daerah maka semakin besar pula sumber kekayaan daerah yang dapat dimanfaatkan oleh pemerintah daerah. Kompleksitas merupakan suatu kondisi dimana terdapat berbagai faktor yang ada dilingkungan internal dan eksternal yang mempengaruhi organisasi. Kompleksitas di pemerintah dapat diartikan sebagai kondisi yang mana terdapat bermacam-macam faktor yang memiliki karakteristik yang berbeda yang dapat mempengaruhi pemerintahan baik secara langsung ataupun tidak langsung (Pamuji, 2017).

Kompleksitas juga didasarkan pada persepsi individu tentang kesulitan tugas atau pekerjaan yang dilakukan. Persepsi ini menimbulkan kemungkinan suatu tugas atau pekerjaan sulit untuk dilakukan. Kompeksitas daerah dapat diukur dengan menggunakan jumlah satuan kerja perangkat daerah (SKPD) yang ada di daerah. Peraturan Pemerintah Nomor 12 Tahun 2019 tentang Pengelolaan Keuangan Daerah, mendefinisikan satuan kerja perangkat daerah (SKPD) merupakan unsur perangkat daerah pada pemerintah daerah yang melaksanakan urusan pemerintah daerah dan pengelolaan keuangan daerah. Dalam melaksanakan tugasnya SKPD membuat dokumen rencana strategis satuan kerja perangkat daerah (Renstra-SKPD) dan rencana kerja satuan kerja perangkat daerah (Renja-SKPD). Dokumen ini disusun secara partisipatif dan melibatkan masyarakat. Dengan adanya rencana kerja perangkat daerah ini akan meningkatkan kinerja pemerintah daerah dalam pembangunan daerah dan menggali kekayaan yang ada di daerah tersebut.

Kekayaan daerah yang dilihat dari total aset daerah berbanding lurus dengan kompleksitas daerah yang diukur dengan jumlah satuan kerja perangkat daerah. Sebab semakin banyak jumlah satuan kerja perangkat daerah maka semakin besar jumlah kekayaan daerah yang ada di daerah tersebut. Selain itu jumlah satuan kerja perangkat daerah (SKPD) juga menjadi pertimbangan dalam meningkatkan pelayanan, sarana dan prasarana publik (Puspitasari, 2013). 
Belanja modal juga bisa meningkatkan kinerja penyelenggaraan pemerintah. Karena dengan adanya upaya pemerintah dalam meningkatkan pelayan dan fasilitas publik konsekuensinya pemerintah daerah harus mengeluarkan alokasi belanja yang lebih besar salah satunya adalah belanja modal (Aryani, 2017). Belanja modal menurut Undang-Undang Nomor 33 Tahun 2004 adalah semua kewajiban daerah yang di akui sebagai pengurangan nilai kekayaan bersih dalam periode tahun anggaran yang bersangkutan. Susanti dan Fahlevi (2016) menjelaskan belanja modal adalah belanja yang digunakan untuk biaya pengeluaran yang dilakukan dalam rangka pembelian dan pengadaan atau pembangunan aset tetap berwujud yang memiliki masa manfaat lebih dari dua belas bulan yang digunakan untuk kegiatan pemerintah, seperti tanah, peralatan dan mesin, gedung dan bangunan, jalan dan irigasi dan aset tetap lainnya.

Alokasi belanja modal dalam bentuk menambah aset tetap digunakan pemerintah untuk kebutuhan daerah baik itu sebagai sarana dan prasarana, atau dalam bentuk pelaksanaan tugas pemerintah daerah atau untuk fasilitas publik. Alokasi belanja modal di daerah belum sepenuhnya terlaksana dengan baik, karena pengelolaan belanja modal belum di prioritaskan bagi kebutuhan dan kesejahteraan publik. Pengelolaan terhadap belanja modal dilakukan oleh satuan kerja perangkat daerah (SKPD), kerena semakin kompleks suatu daerah semakin banyak pengalokasian belanja modal yang dilakukan oleh daerah tersebut. Kompleksitas daerah dilihat dari jumlah satuan kerja perengkat daerahnya. Kerena belanja modal yang dilakukan oleh pemerintah daerah dilaksanakan oleh SKPD yang ada di pemerintah daerah sesuai dengan fungsi dan tugas masing-masing dari SKPD yang bersangkutan. Peraturan Pemerintah Nomor 12 Tahun 2019 tentang Pengelolaan Keuangan Daerah, menyatakan bahwa Satuan kerja perangkat daerah (SKPD) menyusun rencana kerja dan anggaran satuan kerja perangkat daerah (RKA SKPD) yang memuat dokumen rencana pendapatan dan belanja SKPD atau dokumen yang memuat pendapatan, belanja, dan pembiayaan SKPD yang melaksanakan fungsi bendahara umum daerah yang digunakan sebagai dasar penyusunan rencana APBD. Didalam rencana APBD akan memuat seberapa besar belanja modal yang akan dilakukan oleh pemerintah daerah dalam satu tahun anggaran.

Penelitian yang menguji pengaruh kekayaan daerah dan belanja modal terhadap kinerja penyelenggaraan pemerintah daerah pernah dilakukan oleh Mustikarani dan Fitriasari (2011), Harumiati dan Payamta (2014), Ara et al (2016), Qowi dan Prabowo (2017). Hasil penelitiannya menunjukan bahwa kekayaan daerah dan belanja modal berpengaruh terhadap kinerja penyelenggaraan pemerintah daerah. Ini menunjukan bahwa semakin tinggi kekayaan daerah yang dimiliki oleh suatu daerah akan meningkatkan kinerja penyelenggaraan pemerintah daerah dan penelitian ini juga menunjukan bahwa belanja modal yang dialokasikan berdasarkan kebutuhan daerah terhadap sarana dan prasarana publik akan meningkatkan kinerja penyelenggaraan pemerintah.

Artha et al (2015), Utama (2018), juga pernah melakukan penelitian yang menguji pengaruh kekayaan daerah dan belanja modal terhadap kinerja penyelenggaraan pemerintah daerah. Hasil penelitiannya menunjukan bahwa kekayaan daerah dan belanja modal tidak berpengaruh terhadap kinerja penyelnggaraan pemerintah daerah. Ini menunjukan bahwa kekayaan daerah yang ada di daerah tersebut belum sepenuhnya dimanfaatkan oleh pemerintah daerah dalam meningkatkan kinerjanya dan belanja modal di daerah tersebut belum dialokasikan sepenuhnya untuk sarana dan prasarana publik dalam meningkatkan kinerja pemerintah daerah.

Penelitian yang telah dilakukan oleh peneliti terdahulu yang menguji pengaruh kekyaan daerah dan belanja modal terhadap kinerja penyelenggaraan pemerintah daerah masih memiliki perbedaan pada hasil penelitiannya yang disebabkan oleh setiap kondisi daerah yang ada di 
Indonesia memiliki karakteristik yang berbeda dan sumber pemasukan yang berbeda. Perbedaan hasil penelitian tersebut, mendorong peneliti untuk melakukan penelitian mengenai pengaruh kekayaan daerah dan belanja modal terhadap kinerja penyelenggaraan pemerintah. Selain itu penelitian terdahulu belum mempertimbangkan faktor kompleksitas pemerintah daerah terhadap kinerja penyelenggaraan pemerintah daerah sebagai variabel moderasi dalam penelitiannya. Karena semakin kompleks suatu pemerintah daerah dalam menjalankan kegiatan dan fungsi pemerintah maka akan menyebabkan semakin besar tingkat pengungkapan dan kinerja pemerintah daerah tersebut. Kompleksitas pemerintah daerah pada penelitian ini diukur dengan jumlah satuan kerja perangkat daerah (SKPD).

Jumlah SKPD akan menggambarkan jumlah urusan yang menjadi prioritas pemerintah daerah dalam peningkatan kinerja pemerintah daerah dan pembangunan di daerah. Semakin banyak urusan yang dilakukan dan diprioritaskan oleh pemerintah daerah maka semakin kompleks pemerintah daerah dalam melaksanakan tugasnya dan akan meningkatkan kinerja pemerintah daerah dan pembangunan yang ada di daerah. Peneliti menilai bahwa komplesitas daerah bisa memperkuat kinerja penyelenggaraan pemerintah daerah. Karena SKPD merupakan satuan kerja perangkat daerah yang melakukan pelaksanaan fungsi eksekutif yang harus berkoordinasi agar penyelenggaraan pemerintah daerah dapat bejalan dengan baik sesuai dengan dasar hukum pembentukan SKPD yaitu Undang-Undang Nomor 32 Tahun 2004 tentang Pemerintah Daerah.

Penelitian ini bertujuan untuk memberikan bukti empiris mengenai pengaruh kekayaan daerah dan belanja modal terhadap kinerja penyelenggaraan pemerintah daerah kabupaten/kota provinsi Sumatera Barat dan Untuk mengetahui apakah kompleksitas pemerintah akan memperkuat pengaruh kekayaan daerah dan belanja modal terhadap kinerja penyelenggaraan pemerintah daerah tahun 2013-2017. Hasil penelitian ini diharapkan berguna bagi pihak-pihak berkepentingan dalam pengambilan keputusan yang akan meningkatkan kinerja penyelenggaraan pemerintah daerah.

\section{REVIU LITERATUR DAN HIPOTESIS \\ Teori Keagenan (Agency Theory)}

Teori keagenan (agency theory) adalah teori yang menjelaskan hubungan antara principal (pemilik) dengan agent (manajer) dalam menjalankan suatu perusahaan. Jensen dan Meckling (1976), menyatakan bahwa hubungan keagenan merupakan sebuah persetujuan (kontrak) antara dua pihak, yaitu principal dan agent untuk mengambil keputusan atas nama principal. Di pemerintahan daerah teori keagenan bisa dilihat dari hubungan antara pemerintahan pusat dan pemerintahan daerah. Selain itu bisa dilihat juga dari hubungan antara pemerintah daerah dan masyarakat, masyarakat sebagai principal memberikan kepercayaan kepada pemerintah untuk mengelola sumber daya daerah mereka. Pemerintah sebagai agent yang harusnya mengelola semua sumber kekayaan daerah harus sesuai dengan semestinya. Pemerintah sudah seharusnya memberikan timbal balik kepada masyarakat dalam bentuk pelayan publik yang memadai (Aryani, 2017).

\section{Signalling Teori}

Menurut Brigham dan Houston (1999), signalling theory adalah tindakan perusahaan dalam memberikan sinyal kepada investor tentang bagaimana manajemen memandang perusahaan. Signalling theory mambahas bagaimana seharusnya sinyal keberhasilan atau kegagalan manajemen (agent) disampaikan kepada pemilik (prinsipal). Dalam pemerintahan konteks 
signalling teori ini bisa dilihat dari hubungan antara pemerintahan daerah dan pemerintahan pusat, yang mana pemerintahan pusat memberikan dana kepada pemerintahan daerah (dana perimbangan) unuk meningkatkan pembangunan dan infrastruktur pemerintahan daerah. Signalling theory juga bisa dilihat dari hubungan antara pemerintah dan masyarakat, pemerintah berusaha untuk memberikan sinyal yang baik kepada rakyat. Tujuannya agar rakyat dapat terus mendukung pemerintah yang saat ini berjalan dengan baik. Laporan keuangan dapat dijadikan sarana untuk memberikan sinyal kepada rakyat (Hilmi dan Martani, 2013).

\section{Kinerja Penyelenggaraan Pemerintah Daerah}

Peraturan Pemerintah Nomor 13 Tahun 2019 tentang Laporan dan Evaluasi Penyelenggaraan Pemerintah Daerah, menyatakan bahwa kinerja penyelenggaraan pemerintah daerah adalah hasil kinerja dari pemerintah daerah yang dapat diukur dalam penyelenggaraan urusan pemerintah daerah sesuai dengan tanggung jawab dan kewenangan yang dimiliki suatu daerah dalam waktu yang ditentukan. Kinerja yang dilakukan oleh pemerintah daerah akan dilaporkan di laporan penyelenggaraan pemerintah daerah (LPPD).

Laporan kinerja penyelenggaraan pemerintah daerah akan dinilai oleh tim khusus dari pemerintah pusat dalam bentuk evaluasi kinerja penyelenggaraan pemerintah daerah (EKPPD). Tujuan dilakukannya evaluasi kinerja penyelenggaraan pemerintah daerah adalah untuk menilai kinerja penyelenggaraan pemerintah daerah dalam upaya meningkatkan kinerja pemerintah daerah berdasarkan prinsip tata kelola pemerintahan yang baik.

\section{Kekayaan Daerah}

Kekayan daerah merupakan suatu bentuk sumber daya yang dimiliki oleh pemerintah daerah yang digunakan pemerintah untuk melaksanakan fungsi pelayanan kepada masyarakat (Siddi,2016). Kekayaan daerah akan menggambarkan pendapatan yang berasal dari daerah itu sendiri dan dapat menggambarkan madiri atau tidaknya daerah itu dalam membiayai pengeluaran daerahnya (Sedyaningsih dan Zaky, 2013). Dalam melakukan pelayanan yang baik kepada masyarakat harus didukung dengan kekayaan daerah yang baik juga. Kekayaan daerah juga dapat diukur dengan melihat total aset yang ada di daerah tersebut (Pratama dan Sujana, 2015). Karena aset merupakan sumber daya ekonomi yang dimilki oleh daerah sebagai akibat dari peristiwa masa lalu dan manfaat ekonomi dan sosial dimasa depan yang diharapkan dapat dimanfaatkan secara baik oleh masyarakat.

\section{Belanja Modal}

Undang-Undang Nomor 33 Tahun 2004 tentang perimbangan keuangan antara pemerintah pusat dan daerah, mendefinisikan belanja modal adalah semua kewajiban daerah yang di akui sebagai pengurangan nilai kekayaan bersih dalam periode tahun anggaran yang bersangkutan. Alokasi belanja modal akan menunjang aktifitas masyarakat yang nantinya akan meningkatkan pertumbuhan ekonomi masyarakat. Peningkatan pertumbuhan ekonomi masyarakat tumbuh karena adanya dukungan dari fasilitas yang diberikan oleh pemerintah dari alokasi belanja modal, sehingga menarik investor luar untuk menginvestasikan dananya kepada pemerintah daerah dalam meningkatkan pembangunan daerah (Kadafi, 2013).

\section{Kompleksitas Pemerintah}

Kompleksitas di pemerintah daerah diartikan sebagai suatu kondisi dimana terdapat bermacammacam faktor dengan karakteristik berbeda yang dapat mempengaruhi pemerintah baik secara langsung atau tidak langsung (Maulana, 2015). Kompleksitas didasari pada pemikiran individu tentang kesulitan dalam melakukan tugas atau pekerjaan. Pemikiran ini menimbulkan dugaan 
bahwa suatu pekerjaan akan sulit dilakukan oleh seseorang atau mudah dilakukan oleh orang lain (Puspitasari, 2013). Semakin kompleks suatu pemerintah daerah maka semakin besar tingkat pengungkapan yang harus dilakukan oleh pemerintah daerah tersebut. Kompleksitas pemerintah dapat diukur dengan melihat jumlah satuan kerja perangkat daerah (SKPD) yang ada di daerah.

Jumlah satuan kerja perangkat daerah (SKPD) menjadi salah satu faktor dalam melihat tingkat kebutuhan pelayanan di suatu daerah (Putri, 2015). Satuan kerja perangkat daerah (SKPD) adalah suatu perangkat daerah yang melaksanakan tugas dan fungsi eksekutif yang harus berkoordinasi supaya penyelenggaraan pemerintahan dapat berjalan dengan baik sesuai dengan dasar hukum pembentukan SKPD yaitu Undang-undang Nomor 32 tahun 2004 tentang pemerintah daerah. Jumlah SKPD akan menggambarkan semakin banyak jumlah prioritas dan urusan pemerintah daerah dalam membangun daerah dan meningkatkan kinerja pemerintah.

\section{Pengaruh Kekayaan Daerah Terhadap Kinerja Penyelenggaraan Pemerintah Daerah}

Tingkat kekayaan daerah merupakan suatu bentuk sumber daya yang dimiliki oleh pemerintahan daerah yang digunakan pemerintah untuk melaksanakan fungsi pelayanan kepada masyarakat. Kekayaan daerah berbanding lurus dengan tingkat kepedulian yang dimiliki masyarakat kepada pemerintahan daerah. Pada penelitian ini kekayaan daerah dilihat dari total aset yang dimiliki oleh daerah. Aset adalah sumber daya ekonomi yang dikuasai atau dimiliki pemerintah sebagai akibat dari peristiwa masa lalu dan dari masa manfaat ekonomi dan sosial di masa depan yang diharapakan dapat di peroleh baik oleh pemerintah ataupun masyarakat, dan dapat diukur dalam satuan uang, termasuk sumber daya non keuangan yang diperlukan untuk menyediakan jasa bagi masyarakat umum dan sumber daya yang dipelihara berdasarkan alasan sejarah dan budaya. Kekayaan daerah yang dilihat dari total aset daerah dengan kinerja penyelenggaraan pemerintah memiliki hubungan positif. Karena Aset merupakan sumber daya yang dimiliki oleh pemerintah yang bisa memberikan dampak pada kinerja pemerintahan dalam melakukan pelayanan kepada masyarakat.

Penelitian yang dilakukan oleh Sudarsana dan Rahadjo (2013), Qowi dan Prabowo (2017), Ara et al (2016), Harumiati dan Payamta (2014), Mustikarani dan Fitriasari (2011), menyatakan bahwa tingkat kekayaan daerah memiliki pengaruh terhadap kinerja penyelenggaraan keuangan pemerintah. Berarti semakin tinggi tingkat kekayaan daerah akan meningkatkan kinerja pemerintahan daerah. Dari uraian tersebut maka hipotesis pertama dari penelitian ini adalah:

H1: Kekayaan daerah berpengaruh positif terhadap kinerja penyelenggaraan pemerintah daerah

\section{Pengaruh Belanja Modal Terhadap Kinerja Penyelenggaraan Pemerintah daerah}

Undang-Undang Nomor 33 Tahun 2004 tentang Perimbangan Keuangan antara Pemerintahan Pusat dan Daerah, mendefinisikan belanja modal adalah semua kewajiban daerah yang di akui sebagai pengurangan nilai kekayaan bersih dalam periode tahun anggaran yang bersangkutan. Hubungan belanja modal dengan kinerja penyelanggaraan pemerintah bisa dilihat dari alokasi belanja modal dalam bentuk menambah aset tetap yang digunakan pemerintah untuk kebutuhan daerah baik itu sebagai sarana dan prasarana atau dalam bentuk kinerja yang dilakukan pemerintah dalam upaya meningkatkan fasilitas publik.

Penelitian yang dilakukan oleh Usman dan Misra (2019), Qowi dan Prabowo (2017), Ara et al (2016), Harumiati dan Payamta (2014), Mustikarani dan Fitriasari (2011), menemukan bahwa belanja modal memiliki pengaruh terhadap kinerja penyelenggaraan pemerintah. Berarti belanja modal yang dialokasikan berdasarkan kebutuhan daerah terhadap sarana dan prasarana 
publik akan meningkatkan kinerja penyelenggaraan pemerintah. Dari uraian tersebut maka hipotesis kedua dalam penelitian ini adalah:

H2: Belanja modal berpengaruh positif terhadap kinerja penyelenggaraan pemerintah daerah.

\section{Komplesitas Pemerintah Memperkuat Pengaruh Kekayaan Daerah Terhadap Kinerja Penyelenggaraan Pemerintah Daerah}

Kekayaan daerah harus diperhatikan pemerintah dalam peningkatan kinerja penyelenggaraan pemerintah. Kekayaan daerah yang dimiliki oleh suatu daerah harus dimanfaatkan dengan baik oleh daerah untuk meningkatkan pelayanan, sarana dan prasarana publik. Dalam memanfaatkan kekayaan daerah harus diperhatikan juga kegunaan dari kekayaan daerah tersebut, agar kekayaan daerah bisa dimanfaatkan sesuai dengan kepentingan publik. Sehingga semakin kompleks suatu daerah maka semakin besar pula sumber kekayaan daerah yang dapat dimanfaatkan oleh pemerintah daerah. Jumlah satuan kerja perangkat daerah (SKPD) menjadi pertimbangan dalam meningkatkan pelayanan, sarana dan prasarana publik. SKPD yang ada di pemerintah daerah dapat membantu untuk meningkatkan sumber kekayaan daerah karena SKPD bertugas untuk menggali semua potensi yang ada di daerah.

Kekayaan daerah yang dilihat dari total aset daerah berbanding lurus dengan kompleksitas daerah yang diukur dengan jumlah satuan kerja perangkat daerah. Sebab semakin banyak jumlah satuan kerja perangkat daerah maka semakin besar jumlah kekayaan daerah yang ada di daerah tersebut. Selain itu jumlah satuan kerja perangkat daerah (SKPD) juga menjadi pertimbangan dalam meningkatkan pelayanan, sarana dan prasarana publik. SKPD diyakini dapat memperkuat pengaruh kekayaan daerah dengan kinerja penyelenggaraan pemerintah. Dari uraian tersebut maka hipotesis ketiga dalam penelitian ini adalah:

H3: Kompleksitas pemerintah memperkuat pengaruh kekayaan daerah terhadap kinerja penyelenggaraan pemerintah daerah.

\section{Kompleksitas Pemerintah Memperkuat Pengaruh Belanja Modal Terhadap Kinerja Penyelenggaraan Pemerintah}

Salah satu kunci keberhasilan kinerja penyelenggaraan pemerintah adalah alokasi belanja modal karena belanja modal digunakan pemerintah untuk meningkatkan pelayanan kepada publik. Berdasarkan teori keagenan hubungan antara pemerintah daerah dan masyarakat, pemerintah sebagai agen harus dapat mempertanggung jawabkan anggaran belanja modalnya agar pembangunan dan rencana yang dilakukan pemerintah untuk peningkatan pelayanan publik bisa terlaksanakan.

Pengelolaan terhadap belanja modal dilakukan oleh satuan kerja perangkat daerah (SKPD), kerena semakin kompleks suatu daerah semakin banyak pengalokasian belanja modal yang dilakukan oleh daerah tersebut. Kompleksitas daerah dilihat dari jumlah satuan kerja perengkat daerahnya. Kerena belanja modal yang dilakukan oleh pemerintah daerah dilaksanakan oleh SKPD yang ada di pemerintah daerah sesuai dengan fungsi dan tugas masingmasing dari SKPD yang bersangkutan. Kompleksitas pemerintah yang dilihat dari jumlah SKPD yang ada pemerintah daerah dapat memperkuat hubungan antara belanja modal dengan kinerja penyelenggaraan pemerintah. Dari uraian tersebut maka hipotesis keempat dalam penelitian ini adalah:

H4: Kompleksitas Pemerintah memperkuat pengaruh belanja modal terhadap kinerja penyelenggaraan pemerintah daerah. 


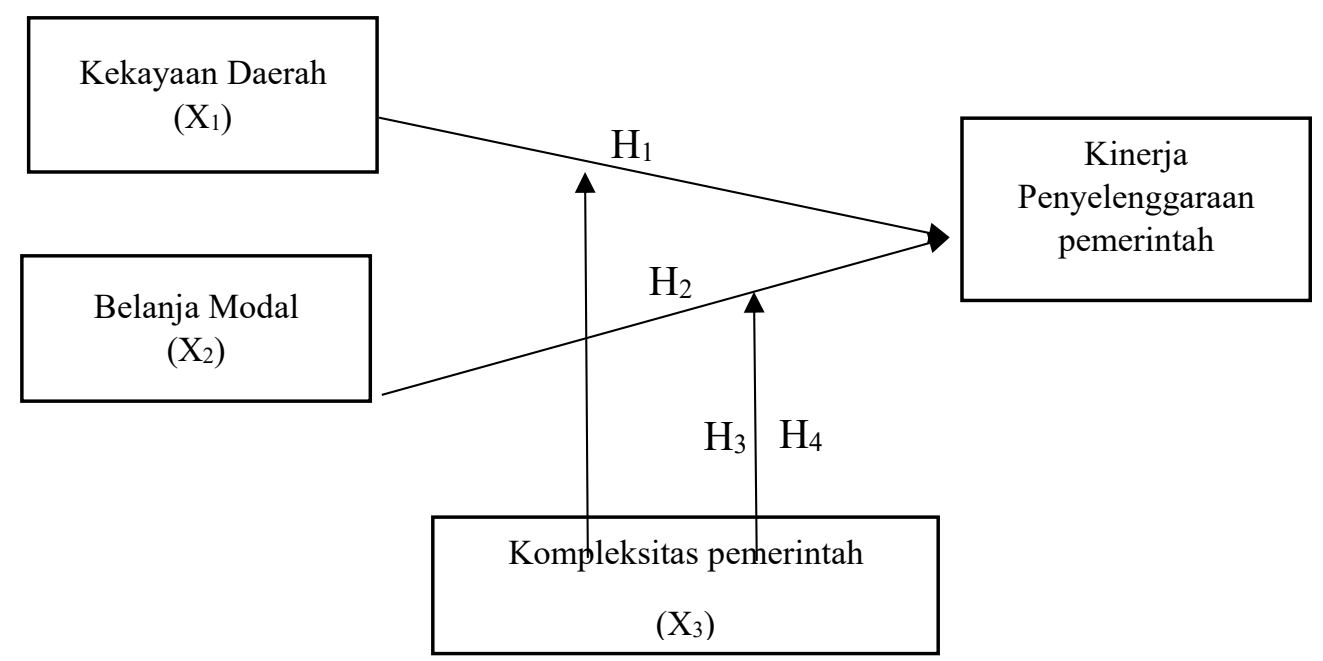

Gambar 1. Kerangka Konseptual

\section{METODE PENELITIAN}

\section{Sampel dan Jenis Penelitian}

Jenis penelitian ini adalah penelitian kausalitas dengan pendekatan kuantitatif. Penelitian kausalitas menjelaskan hubungan sebab akibat antara dua variabel atau lebih sehingga bisa melihat pengaruh antara satu variabel dengan variabel lainnya (Sugiyono, 2008). Populasi dalam penelitian ini adalah sembilan belas (19) kabupaten/kota yang ada di provinsi Sumatera Barat. Pemilihan sampel dalam penelitian ini menggunakan metode total sampling, yaitu semua anggota populasi mempunyai peluang untuk dipilih menjadi anggota sampel.

\section{Jenis, Sumber dan Teknik Pengumpulan Data}

Jenis data yang digunakan dalam penelitian ini adalah data sekunder, yaitu data yang diperoleh, dikumpulkan dan diolah terlebih dahulu oleh pihak lain. Sumber data dalam penelitian ini adalah Laporan Realisasi Anggaran dan Neraca kabupaten/kota provinsi Sumatera Barat yang sudah di audit dan evaluasi kinerja penyelenggaraan pemerintah daerah (EKKPD) kabupaten/kota provinsi Sumatera Barat. Data di peroleh dari situs resmi Badan Pemeriksa Keuangan (BPK) Perwakilan Sumatera Barat (https://padang.bpk.go.id) dan situs resmi Direktorat Jendral Otonomi Daerah (https://otda.kemendagri.go.id).

\section{VARIABEL PENELITIAN DAN PENGUKURAN}

\section{Kinerja Penyelenggaraan Pemerintah Daerah}

Kinerja penyelenggaraan pemerintah daerah adalah hasil kinerja dari pemerintah daerah yang dapat diukur dalam penyelenggaran urusan pemerintah daerah sesuai dengan tanggung jawab dan kewenangan yang dimiliki suatu daerah dalam waktu yang ditentukan. Kinerja penyelenggaraan pemerintah daerah diukur dengan melihat skor hasil evaluasi kinerja penyelenggaraan pemerintah yang berada dalam range nilai 0-4 berdasarkan LPPD tahun 20132017. Karena skor kinerja evaluasi penyelenggaraan pemerintah daerah ini dilakukan berdasarkan penilaian portofolio secara desk evaluation terhadap data yang dimuat dalam laporan penyelenggaraan pemerintah daerah (LPPD) dan penilaian lapangan terhadap prestasi kinerja yang telah dicapai oleh masing-masing pemerintah daerah (Budianto, 2012). 


\section{Kekayaan Daerah}

Kekayan daerah merupakan suatu bentuk sumber daya yang dimiliki oleh pemerintah daerah yang digunakan pemerintah untuk melaksanakan fungsi pelayanan kepada masyarakat. Kekayaan daerah dapat dilihat dari total aset yang dimiliki daerah, karena total aset dapat menggambarkan besarnya sumber daya yang dimiliki oleh suatu daerah. Variabel kekayaan daerah pada penelitian ini diukur menggunakan logaritma natural (Ln) dari total aset, karena total aset yang dimiliki oleh setiap pemerintah daerah berbeda besarnya sehingga memiliki selisih yang besar. Untuk menghidari terjadinya data yang tidak normal maka perlu dilakukan logaritma natural (Ln) untuk total aset dalam penelitian ini. Dengan menggunakan logaritma natural (Ln) nilai miliar atau triliun akan disederhanakan tanpa mengubah proporsi dan nilai aset yang sebenarnya. Kakayaan daerah diukur dengan rumus:

$$
\text { Kekayaan Daerah }=\text { Ln }(\text { Total Aset })
$$

\section{Belanja Modal}

Belanja modal adalah belanja yang digunakan untuk biaya pengeluaran yang dilakukan dalam rangka pembelian dan pengadaan atau pembangunan aset tetap berwujud yang memiliki masa manfaat lebih dari dua belas bulan yang digunakan untuk kegiatan pemerintah, seperti tanah, peralatan dan mesin, gedung dan bangunan, jalan dan irigasi dan aset tetap lainnya. Belanja modal pada penelitian ini diukur dengan melihat perbandingan realisasi belanja modal dengan total realisasi belanja yang terdapat di laporan realisasi anggaran kabupaten/kota provinsi Sumatera Barat tahun 2013-2017. Karena ini akan mencerminkan besarnya belanja daerah yang digunakan untuk membiayai belanja modal. Maka dalam mengukur variabel belanja modal dalam penelitian ini digunakan rumus:

$$
\text { Belanja Modal }=\frac{\text { Realisasi Belanja Modal }}{\text { Total Realisasi Belanja Daerah }}
$$

\section{Kompleksitas Pemerintah}

Kompleksitas pemerintah pada penelitian ini dilihat dari jumlah satuan kerja perangkat daerah (SKPD) yang ada di kabupaten/kota provinsi Sumatera Barat. Kompleksitas pemerintah yang dilihat dari jumlah SKPD dinilai akan mampu memperkuat kinerja penyelenggaraan pemerintah, karena selain bertugas untuk membantu kepala daerah menjalankan tugas pemerintahan SKPD juga bertugas untuk menggali potensi yang ada di daerah dan meningkatkan pelayanan kepada masyarakat. Variabel kompleksitas pemerintah pada penelitian ini diukur menggunakan logaritma natural (Ln) dari jumlah SKPD, karena jumlah SKPD yang dimiliki oleh setiap pemerintah daerah berbeda jumlahnya dan untuk menghidari terjadinya data yang tidak normal maka perlu dilakukan logaritma natural (Ln) untuk jumlah SKPD dalam penelitian ini. Kompleksitas pemerintah diukur dengan rumus:

$$
\text { Kompleksitas pemerintah }=\text { Ln (Jumlah SKPD) }
$$

\section{Metode Analisis Data}

Analisis data pada penelitian ini diuji menggunakan program SPSS 22. Dengan menggunakan model regresi linear berganda dengan metode moderate regreesion analysis, dengan persamaan:

$$
\begin{aligned}
& \mathrm{Y}=\alpha+\beta 1 \mathrm{KD}+\beta 2 \mathrm{BM}+\mathrm{e} . \ldots \ldots \ldots \ldots \ldots \\
& \mathrm{Y}=\alpha+\beta 1 \mathrm{KD}+\beta 3 \mathrm{KP}+\beta 4 \mathrm{KD} . \mathrm{KP}+\mathrm{e} \\
& \mathrm{Y}=\alpha+\beta 2 \mathrm{BM}+\beta 3 \mathrm{KP}+\beta 5 \mathrm{BM} . \mathrm{KP}+\mathrm{e}
\end{aligned}
$$




\section{HASIL DAN PEMBAHASAN \\ Analisis Deskrptif}

Tabel 1

Hasil statistik deskriptif

Descriptive Statistics

\begin{tabular}{|l|r|r|r|r|r|}
\hline & $\mathrm{N}$ & Minimum & Maximum & \multicolumn{1}{c|}{ Mean } & \multicolumn{1}{c|}{$\begin{array}{c}\text { Std. } \\
\text { Deviation }\end{array}$} \\
\hline $\begin{array}{l}\text { Kinerja Penyelenggaraan } \\
\text { Pemerintah Daerah }\end{array}$ & 79 & 2,37 & 3,40 & 2,9401 &, 21833 \\
\hline Kekayaan Daerah & 79 & 27,19 & 28,73 & 27,9813 &, 30688 \\
\hline Belanja Modal & 79 &, 12 &, 35 &, 2252 &, 05641 \\
\hline Kompleksitas Pemerintah & 79 & 3,30 & 3,87 & 3,5892 &, 16821 \\
\hline Valid N (listwise) & 79 & & & & \\
\hline
\end{tabular}

Sumber: Data Olahan SPSS 22, 2020

Hasil uji statistik deskriptif terhadap kinerja penyelenggaraan pemerintah daerah menunjukan nilai minimum 2,37 dan nilai maksimum 3,40 dengan nilai rata-rata 2,9401 dan standar deviasi 0, 21833. Variabel independen pertama pada penelitian ini adalah kekayaan daerah. Hasil uji statistik deskriptif terhadap kekayaan daerah menunjukan nilai minimum 27,19 dan nilai maksimum 28,73 dengan nilai rata-rata 27,9813 dan standar deviasi 0,30688. Variabel independen kedua pada peelitian ini adalah belanja modal. Hasil uji statistik deskriptif terhadap belanja modal menunjukan nilai minimum 0,12 dan nilai maksimum 0,35 dengan nilai rata-rata 3,5892 dan standar deviasi 0,05641.Variabel moderasi pada penelitian ini adalah kompleksitas pemerintah. Hasil uji statistik deskriptif terhadap kompleksitas pemerintah menunjukan nilai minimum 3,30 dan nilai maksimum 3,87 dengan nilai rata-rata 3,16716 dan standar deviasi 0,16821 .

\section{UJI ASUMSI KLASIK}

Uji Normalitas

Tabel 2

Hasil Uji Normalitas (One-Sample Kolmogorof-Smirnof Test) One-Sample Kolmogorov-Smirnov Test

\begin{tabular}{|ll|r|}
\hline & & \multicolumn{1}{|c|}{ Unstandardized Residual } \\
\hline Normal Parameters & & 79 \\
& &, 0000000 \\
Most Extreme Differences & Mean &, 21093714 \\
& Std. Deviation &, 095 \\
& Absolute &, 065 \\
& Positive &,- 095 \\
Test Statistic & Negative &, 095 \\
Asymp. Sig. (2-tailed) & &, $074^{\mathrm{c}}$ \\
\hline
\end{tabular}

a. Test distribution is Normal.

b. Calculated from data.

c. Lilliefors Significance Correction.

Sumber: Data Olahan SPSS 22, Tahun 2020 
Tabel diatas menunjukan hasil uji normalitas dengan One-Sample Kolmogorof-Smirnov Test. Hasil uji normalitas pada penelitian ini memiliki probabilitas tingkat signifikasi 0,074 di atas nilai signifikasi kepercayaan 0,05. Ini berarti data penelitian ini berdistribusi secara normal.

\section{Uji Multikolonioritas}

Tabel 3

Hasil Uji Multikolineoritas

Coefficients $^{\mathrm{a}}$

\begin{tabular}{|c|c|c|c|c|c|c|c|}
\hline \multirow[b]{2}{*}{ Model } & \multicolumn{2}{|c|}{$\begin{array}{c}\text { Unstandardized } \\
\text { Coefficients }\end{array}$} & \multirow{2}{*}{$\begin{array}{c}\begin{array}{c}\text { Standardized } \\
\text { Coefficients }\end{array} \\
\text { Beta }\end{array}$} & \multirow[b]{2}{*}{$\mathrm{T}$} & \multirow[b]{2}{*}{ Sig. } & \multicolumn{2}{|c|}{$\begin{array}{c}\text { Collinearity } \\
\text { Statistics }\end{array}$} \\
\hline & $\mathrm{B}$ & Std. Error & & & & Tolerance & VIF \\
\hline (Constant) & 2,153 & 2,473 & & 871 & ,387 & & \\
\hline $\begin{array}{l}\text { Kekayaan } \\
\text { Daerah }\end{array}$ & ,029 & ,101 & ,041 & ,287 & ,775 & ,615 & 1,626 \\
\hline Belanja Modal &,- 933 & ,436 &,- 241 & $-2,138$ &, 036 & ,980 & 1,021 \\
\hline $\begin{array}{l}\text { Kompleksitas } \\
\text { Pemerintah }\end{array}$ &, 052 & , 186 & 040 & ,278 &, 782 & ,605 & 1,652 \\
\hline
\end{tabular}

a. Dependent Variable: Kinerja Penyelenggaraan Pemerintah Daerah

Berdasarkan tabel diatas tidak ada variabel bebas yang memiliki nilai tolerance kurang dar 0,10 . Hasil perhitungan VIF juga menunjukan hal yang sama yaitu tidak ada satupun variabel bebas yang memiliki nilai VIF lebih besar dari 10. Sehingga disimpulkan bahwa tidak terjadi multikolineoritas pada variabel bebas dalam penelitian ini.

\section{Uji Autokorelasi}

\section{Tabel 4}

Hasil Uji Autokorelasi

Model Summary

\begin{tabular}{|l|l|r|r|r|r|}
\hline Model & R & R Square & Adjusted R Square & Std. Error of the Estimate & Durbin-Watson \\
\hline 1 &, $141^{\mathrm{a}}$ &, 020 &,- 020 &, 07246 & 1,814 \\
\hline
\end{tabular}

a. Predictors: (Constant), Kompleksitas Pemerintah, Belanja Modal, Kekayaan Daerah

b. Dependent Variable: Kinerja Penyelenggaraan Pemerintah Daerah

Sumber: Data Olahan SPSS 22, Tahun 2020

Berdasarkan tabel di atas dapat diketahui bahwa nilai Durbin Watson (DW) adalah sebesar 1,814. Jika dilihat pada tabel DW dengan $\mathrm{n}=79$ dan $\mathrm{K}=3$, maka nilai dU adalah sebesar 1,7141 , dan hasil 4 - dU adalah sebesar 2,2859. Maka dapat disimpulkan bahwa nilai DW yaitu 1,814 berada di antara dU dan $4-\mathrm{dU}$, maka dapat dikatakan bahwa model regresi ini tidak megandung masalah autokolerasi. 
Tabel 5

Hasil Uji Heteroskedetisitas

Coefficients $^{\mathbf{a}}$

\begin{tabular}{|c|c|c|c|c|c|}
\hline \multirow[b]{2}{*}{ Model } & \multicolumn{2}{|c|}{$\begin{array}{c}\text { Unstandardized } \\
\text { Coefficients }\end{array}$} & \multirow{2}{*}{$\begin{array}{c}\begin{array}{c}\text { Standardized } \\
\text { Coefficients }\end{array} \\
\text { Beta } \\
\end{array}$} & \multirow[b]{2}{*}{$\mathrm{T}$} & \multirow[b]{2}{*}{ Sig. } \\
\hline & B & Std. Error & & & \\
\hline 1 (Constant) &,- 998 & 2,091 & &,- 478 & 634 \\
\hline Kekayaan Daerah & ,794 & 1,145 & 091 & 694 & 490 \\
\hline Belanja Modal &,- 022 & ,041 &,- 063 &,- 544 & ,588 \\
\hline $\begin{array}{l}\text { Kompleksitas } \\
\text { Pemerintah }\end{array}$ & 119, & ,260 & 060 & 458 & 648 \\
\hline
\end{tabular}

a. Dependent Variable: Kinerja Penyelenggaraan Pemerintah Daerah Sumber: Data Olahan SPSS 22, Tahun 2020

Berdasarkan tabel di atas dapat diketahui bahwa nilai signifikan kekayaan daerah adalah sebesar 0,490 >0,05, nilai sigifikan belanja modal adalah sebesar 0,81 $>0,588$ dan nilai signifikan kompleksitas pemerintah adalah sebesar $0,648>0,05$. Dari hasil tersebut dapat disimpulkan bahwa model regresi tidak terdapat gejala heteroskedetisitas.

\section{UJI KELAYAKAN MODEL \\ Uji Koofesien Determinasi (R2)}

\section{Tabel 6}

Uji Koofesien Determinasi (Adjusted R-Square) untuk H1 dan H2 Model Summary

\begin{tabular}{|l|r|r|r|r|}
\hline Model & \multicolumn{1}{|c|}{ R } & \multicolumn{1}{|c|}{ R Square } & Adjusted R Square & Std. Error of the Estimate \\
\hline 1 &, $256^{\mathrm{a}}$ &, 066 &, 041 &, 21380 \\
\hline
\end{tabular}

a. Predictors: (Constant), Belanja Modal, Kekayaan Daerah

Sumber: Data Olahan SPSS 22, Tahun 2020

Berdasarkan hasil pengujian tabel 6 diatas nilai R-square (R2) sebesar 0,066 atau 6,6\%. Artinya variabel dependen kinerja penyelenggaraan pemerintah daerah dapat dijelaskan secara signifikan oleh variabel independen kekayaan daerah dan belanja modal sebesar 6,6\%. Sedangkan sisanya sebesar 93,4\% dijelaskan oleh variabel lain yang tidak diamati dalam penelitian ini.

Tabel 7

Uji Koofesien Determinasi (Adjusted R-Square) untuk H3 Model Summary

\begin{tabular}{|l|r|r|r|r|}
\hline Model & R & R Square & Adjusted R Square & Std. Error of the Estimate \\
\hline 1 &, $099^{\mathrm{a}}$ &, 010 & &,- 030 \\
\hline
\end{tabular}

a. Predictors: (Constant), Kekayaan Daerah*Kompleksitas Pemerintah, Kekayaan Daerah, Kompleksitas Pemerintah

Sumber: Data Olahan SPSS 22, Tahun 2020 
Berdasarkan hasil pengujian tabel 7 diatas nilai R-square (R2) sebesar 0,010 atau 1,0\%. Artinya variabel dependen kinerja penyelenggaraan pemerintah daerah dapat djelaskan secara signifikan oleh variabel independen kekayaan daerah, kompleksitas pemerintah dan interaksi hubungan antara kekayaan daerah dengan kompleksitas pemerintah sebesar 1,0\%. Sedangkan sisanya sebesar 99,0\% dijelaskan oleh variabel lain yang tidak diamati dalam penelitian ini.

\section{Tabel 8}

Uji Koofesien Determinasi (Adjusted R-Square) untuk H4 Model Summary

\begin{tabular}{|l|l|r|r|r|}
\hline Model & R & R Square & Adjusted R Square & Std. Error of the Estimate \\
\hline 1 &, $296^{\mathrm{a}}$ &, 087 &, 051 &, 21270 \\
\hline
\end{tabular}

a. Predictors: (Constant), Belanja Modal*Kompleksitas Pemerintah, Kompleksitas Pemerintah, Belanja Modal

Sumber: Data Olahan SPSS 22, Tahun 2020

Berdasarkan hasil pengujian tabel 8 diatas nilai R-square (R2) sebesar 0,087 atau 8,7\%. Artinya variabel dependen kinerja penyelenggaraan pemerintah daerah dapat djelaskan secara signifikan oleh variabel independen belanja modal, kompleksitas pemerintah dan interaksi hubungan antara belanja modal dengan kompleksitas pemerintah sebesar 8,7\%. Sedangkan sisanya sebesar $91,3 \%$ dijelaskan oleh variabel lain yang tidak diamati dalam penelitian ini.

\section{UJI STATISTIK F}

Tabel 9. Uji Statistik F untuk H1 dan H2 ANOVA $^{\mathrm{a}}$

\begin{tabular}{|ll|r|r|r|r|r|}
\hline & & \multicolumn{1}{|c|}{ Sum of } & & & \\
Model & Squares & Df & Mean Square & F & \multicolumn{1}{c|}{ Sig. } \\
\hline 1 & Regression &, 244 & 2 &, 122 & 2,668 &, $076^{\mathrm{b}}$ \\
& Residual & 3,474 & 76 &, 046 & & \\
& Total & 3,718 & 78 & & & \\
\hline
\end{tabular}

a. Dependent Variable: Kinerja Penyelenggaraan Pemerintah Daerah

b. Predictors: (Constant), Belanja Modal, Kekayaan Daerah

Sumber: Data Olahan SPSS 22, Tahun 2020

Berdasarkan tabel 9 diatas, dapat dilihat bahwa nilai Signifikan hasil uji $\mathrm{F}$ adalah sebesar 0,076. Dasar pengambilan keputusan adalah tingkat signifikannya sebesar 5\% atau 0,05 . Karena nilai signifikansi lebih besar dari 0,05 menunjukkan bahwa tidak adanya pengaruh kekayaan daerah dan belanja modal secara bersama-sama terhadap kinerja penyelenggaraan pemerintah daerah. 
Tabel 10

Uji Statistik F untuk H3

ANOVA $^{\mathrm{a}}$

\begin{tabular}{|ll|r|r|r|r|r|}
\hline Model & & \multicolumn{1}{|c|}{$\begin{array}{c}\text { Sum of } \\
\text { Squares }\end{array}$} & Df & Mean Square & F & \multicolumn{1}{c|}{ Sig. } \\
\hline 1 & Regression &, 036 & 3 &, 012 &, 245 &, $864^{\mathrm{b}}$ \\
& Residual & 3,682 & 75 &, 049 & & \\
& Total & 3,718 & 78 & & & \\
\hline
\end{tabular}

a. Dependent Variable: Kinerja Penyelenggaraan Pemerintah Daerah

b. Predictors: (Constant), Kekayaan Daerah*Kompleksitas Pemerintah, Kekayaan

Daerah, Kompleksitas Pemerintah

Sumber: Data olahan SPSS 22, Tahun 2020

Pada hasil uji ANOVA menunjukkan nilai $\mathrm{F}$ hitung sebesar 0,245 dengan probabilitas signifikan sebesar 0,864 . Dengan demikian nilai signifikasi $>0,05$ maka model regresi yang digunakan tidak bisa memprediksi hubungan antara kekayaan daerah dengan kinerja penyelenggaraan pemerintah daerah dengan kompleksitas pemerintah sebagai variabel moderasi.

Tabel 11

Uji Statistik F untuk H4

ANOVA $^{\mathrm{a}}$

\begin{tabular}{|ll|r|r|r|l|l|}
\hline Model & & \multicolumn{1}{|c|}{$\begin{array}{c}\text { Sum of } \\
\text { Squares }\end{array}$} & \multicolumn{1}{c|}{ Df } & Mean Square & F & \multicolumn{1}{c|}{ Sig. } \\
\hline 1 & Regression &, 325 & 3 &, 108 & 2,394 &, $075^{\text {b }}$ \\
& Residual & 3,393 & 75 &, 045 & & \\
& Total & 3,718 & 78 & & & \\
\hline
\end{tabular}

a. Dependent Variable: Kinerja Penyelenggaraan Pemerintah Daerah

b. Predictors: (Constant), Belanja Modal*Kompleksitas Pemerintah, Kompleksitas

Pemerintah, Belanja Modal

Sumber: Data Olahan SPSS 22, Tahun 2020

Pada hasil uji ANOVA menunjukkan nilai $\mathrm{F}$ hitung sebesar 2,394 dengan probabilitas signifikan sebesar 0,075. Dengan demikian nilai signifikasi $>0,05$ maka model regresi yang digunakan tidak bisa memprediksi hubungan antara belanja modal dengan kinerja penyelenggaraan pemerintah daerah dengan kompleksitas pemerintah sebagai variabel moderasi. 


\section{UJI HIPOTESIS}

\section{Uji Signifikasi Parameter Individual (Uji Statistik t)}

Tabel 12

\section{Hasil Uji Signifikasi Parameter Individual (Uji Statistik t) untuk H1 dan H2 Coefficients ${ }^{\mathrm{a}}$}

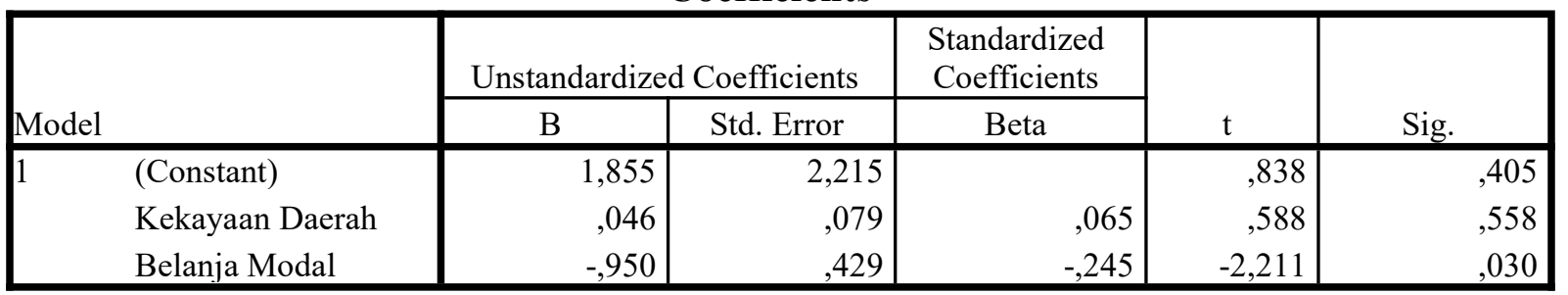

a. Dependent Variable: Kinerja Penyelenggaraan Pemerintah Daerah

Sumber: Data Olahan SPSS 22, Tahun 2020

Dari hasil uji signifikasi parameter individuai (uji statistik $\mathrm{t}$ ) diatas dapat diketahui bahwa variabel independen kekayaan daerah memiliki nilai t hitung sebesar 0,588 dengan tingkat signifikan 0,588 lebih besar dari 0,05 . Artinya hipotesis 1 pada penelitian ini ditolak, dengan kata lain kekayaan daerah tidak berpengaruh terhadap kinerja penyelenggaraan pemerintah daerah. Variabel inependen kedua yaitu belanja modal memiliki nilai t hitung sebesar -2,211 dengan tingkat signifikan 0,030 lebih kecil dari 0,05. Artinya hipotesis 2 ditolak, dengan kata lain kekayaan daerah berpengaruh negatif terhadap kinerja penyelenggaraan pemerintah daerah.

\section{Tabel 13 \\ Hasil Uji Signifikasi Parameter Individual (Uji Statistik t) untuk H3 Coefficients $^{\mathrm{a}}$}

\begin{tabular}{|c|c|c|c|c|c|}
\hline \multirow[b]{2}{*}{ Model } & \multicolumn{2}{|c|}{$\begin{array}{c}\text { Unstandardized } \\
\text { Coefficients }\end{array}$} & \multirow{2}{*}{$\begin{array}{l}\text { Standardized } \\
\text { Coefficients } \\
\text { Beta }\end{array}$} & \multirow[b]{2}{*}{$\mathrm{T}$} & \multirow[b]{2}{*}{ Sig. } \\
\hline & $\mathrm{B}$ & Std. Error & & & \\
\hline (Constant) & 1,856 & 24,117 & & ,077 & ,939 \\
\hline Kekayaan Daerah & ,020 & 677 & ,028 &, 030 & 976 \\
\hline $\begin{array}{l}\text { Kompleksitas } \\
\text { Pemerintah }\end{array}$ & 496 & 19,234 & ,107 & 026 & 979 \\
\hline $\begin{array}{l}\text { Kekayaan } \\
\text { Daerah*Kompleksitas } \\
\text { Pemerintah }\end{array}$ &,- 001 & 192 &,- 028 &,- 006 & 995 \\
\hline
\end{tabular}

a. Dependent Variable: Kinerja Penyelenggaraan Pemerintah Daerah

Sumber: Data Olahan SPSS 22, Tahun 2020

Tabel diatas menjelaskan bahwa variabel moderasi yang merupakan interaksi antara kekayaan daerah dengan kompleksitas pemerintah memiliki nlai t hitung sebesar -0,006 dengan tingkat signifikan 0,995 besar dari 0,05 . Artinya hipotesis 3 ditolak dengan kata lain interaksi antara kekayaan daerah dengan kompleksitas pemerintah tidak memiliki pengaruh signifikan terhadap kinerja penyelenggaraan pemerintah daerah. 


\section{Tabel 14}

\section{Hasil Uji Signifikasi Parameter Individual (Uji Statistik t) untuk H4}

Coefficients $^{\mathbf{a}}$

\begin{tabular}{|c|c|c|c|c|c|c|}
\hline \multirow{2}{*}{\multicolumn{2}{|c|}{ Model }} & \multicolumn{2}{|c|}{$\begin{array}{c}\text { Unstandardized } \\
\text { Coefficients }\end{array}$} & \multirow{2}{*}{$\begin{array}{c}\begin{array}{c}\text { Standardized } \\
\text { Coefficients }\end{array} \\
\text { Beta }\end{array}$} & \multirow[b]{2}{*}{$\mathrm{T}$} & \multirow[b]{2}{*}{ Sig. } \\
\hline & & B & Std. Error & & & \\
\hline \multirow[t]{4}{*}{1} & (Constant) &,- 065 & 2,237 & &,- 029 & ,977 \\
\hline & Belanja Modal & 12,466 & 10,003 & 3,221 & 1,246 & ,217 \\
\hline & $\begin{array}{l}\text { Kompleksitas } \\
\text { Pemerintah }\end{array}$ &, 896 & ,622 & ,690 & 1,440 & , 154 \\
\hline & $\begin{array}{l}\text { Belanja } \\
\text { Modal*Kompleksitas } \\
\text { Pemerintah }\end{array}$ & $-3,740$ & 2,791 & $-3,437$ & $-1,340$ & , 184 \\
\hline
\end{tabular}

a. Dependent Variable: Kinerja Penyelenggaraan Pemerintah Daerah

Sumber: Data Olahan SPSS 22, Tahun 2020

Tabel diatas menjelaskan bahwa variabel moderasi yang merupakan interaksi antara belanja modal dengan kompleksitas pemerintah memiliki nlai t hitung sebesar $-1,340$ dengan tingkat signifikan 0,184 besar dari 0,05. Artinya hipotesis 4 ditolak dengan kata lain interaksi antara belanja modal dengan kompleksitas pemerintah tidak memiliki pengaruh signifikan terhadap kinerja penyelenggaraan pemerintah daerah.

\section{PEMBAHASAN}

\section{Pengaruh Kekayaan Daerah Terhadap Kinerja Penyelenggaraan pemerintah Daerah}

Hipotesis pertama (H1) dalam penelitian ini yaitu kekayaan daerah berpengaruh positif terhadap kinerja penyelenggaraan pemerintah daerah. Dapat diketahui dari hasil uji satatistik $t$ untuk variabel kekayaan daerah memiliki nilai t hitung sebesar 1,083 dengan tingkat signifikan 0,282 lebih besar dari 0,05 sehingga $\mathrm{H} 1$ ditolak. Artinya kekayaan daerah tidak berpengaruh terhadap kinerja penyelenggaraan pemerintah daerah.

Hasil ini memiliki arti bahwa besarnya jumlah kekayaan daerah yang dilihat dari total aset daerah tidak menjamin daerah tersebut memiliki kinerja penyelenggaraan daerah yang baik. Dari perspektif teori keagenan, keberhasilan pemerintah daerah dalam menjalankan perannya sebagai agen dari pemerintah pusat dapat dilihat dari kinerja pemerintahan daerah dalam melaksanakan wewenang pengelolaan sumberdaya daerah yang dapat dilihat dari besarnya total aset yang dimiliki oleh daerah tersebut. Tidak berpengaruhnya kekayaan daerah yang dilihat dari total aset terhadap kinerja penyelenggaraan pemerintah daerah mengindikasikan bahwa peran total aset dalam meningkatkan kinerja penyelenggaraan pemerintah daerah belum berjalan sebagaimana mestinya. Ini disebabkan oleh permasalahan dalam pengeloaan aset di daerah yang belum baik dan optimal serta memungkinkan menjadi penyebab tidak berengaruhnya kekayaan daerah yang dilihat dari total aset terhadap kinerja penyelenggaraan pemerintah daerah.

Penelitian ini sejalan dengan penelitian yang dilakukan oleh Sedyaningsih dan Zaky (2013), Sudarsana (2013), Harumiati dan Payamta (2015), Utama (2018), Usman dan Misra (2019) yang menyatakan bahwa kekayaan daerah yang diukur dengan total aset tidak berpengaruh terhadap kinerja penyelenggaraan pemerintah daerah. Hal ini menunjukan bahwa peran total aset dalam meninigkatkan kinerja penyelenggaraan pemerintah daerah belum berjalan sesuai dengan semestinya. 


\section{Pengaruh Belanja Modal Terhadap Kinerja Penyelenggaraan Pemerintah Daerah}

Hipotsis kedua (H2) dalam penelitian ini yaitu belanja modal berpengaruh positif terhadap kinerja penyelenggaraan pemerintah daerah. Diketahui bahwa dari hasil uji statistik $\mathrm{t}$ variabel belanja modal memiliki nilai t hitung sebesar -2,211 dengan tingkat signifikan 0,030 lebih kecil dari 0,05. Artinya hipotesis 2 ditolak, dengan kata lain belanja modal berpengaruh negatif terhadap kinerja penyelenggaraan pemerintah daerah.

Pengaruh negatif belanja modal terhadap kinerja penyelenggaraan pemerintah daerah mengindikasikan bahwa belanja modal yang tinggi tidak digunakan dalam meningkatkan pelayan terhadap masyarakat sehingga kenaikan belanja modal semakin menurunkan kinerja penyelenggaraan pemerintah daerah. Semakin tingginya belanja modal daerah seharusnya memberikan dampak yang positif terhadap kinerja penyelenggaraan pemerintah daerah tersebut. Dalam perspektif teori keagenan hal ini sangat memungkinkan terjadi karena dalam konteks hubungan keagenan pemerintah daerah terdapat kecendrungan masing-masing pihak melakukan moral hazard dalam rangka memaksimalkan utility-nya sendiri. Saat dilakukannya proses penganggaran belanja modal memungkinkan terjadinya budgetary slack, yaitu kondisi dimana jumlah belanja modal yang dianggarkan tidak mencerminkan kapasitas atau kemampuan belanja modal yang sebenarnya, sehingga kinerja penyelenggaraan pemeintah daerah yang dihasilkan tidak optimal.

Penelitian ini sejalan dengan penelitian yang dilakukan oleh Qowi dan Prabowo (2017), Harumiaty dan Payamta (2015), Mustikarani dan Fitriasari (2011) yang menyatakan bahwa belanja modal berpengaruh negatif terhadap kinerja penyelenggaraan pemerintah daerah. Hai ini menunjukan bahwa semakin besar belanja modal yang dimilki daerah akan menurunkan kinerja penyelenggaraan pemerintah daerah.

\section{Pengaruh Kekayaan Daerah Terhadap Kinerja Penyelenggaraan Pemerintah Daerah Dengan Kompleksitas Pemerintah Sebagai Variabel Moderasi}

Hipotesi ketiga (H3) dalam penelitian ini yaitu kompleksitas pemerintah memperkuat pengaruh kekayaan daerah terhadap kinerja penyelenggaraan pemerintah daerah. Diketahui bahwa dari hasil uji statistik $t$, interaksi antara kekayaan daerah dengan kompleksitas pemerintah memiliki nlai t hitung sebesar -0,006 dengan tingkat signifikan 0,995 besar dari 0,05. Artinya hipotesis 3 ditolak dengan kata lain interaksi antara kekayaan daerah dengan kompleksitas pemerintah tidak memiliki pengaruh signifikan terhadap kinerja penyelenggaraan pemerintah daerah.

Pengelolaan kekayaan daerah tidak terlepas dari peran SKPD sesuai dengan fungsi dan tugasnya. Namun peran SKPD dalam melakukan pengelolaan terhadap kekayaan daerah belum berjalan sesuai dengan mestinya, ini bisa dilihat dari masih terdapatnya beberapa permasalahan dalam pengelolaan aset seperti panyalahgunaan kas dan persediaan. Menurut teori keagenan terdapat hubungan keagenan antara lemabaga eksekutif (SKPD) dan masyarakat, dimana SKPD dalam melaksanakan tugasnya harus mewakili kepentingan dari masyarakat. Namun kenyataannya SKPD tidak selalu bisa mewakili kepentingan dari masyarakat. SKPD memiliki banyak informasi terkait dengan kekayaan daerah atau aset yang ada didaerah dibandingkan masyarakat, ini memungkinkan terjadinya peluang untuk melakukan kecurangan terhadap kekayaan daerah atau aset daerah yang mengakibatkan rendahya kinerja penyelenggaraan pemerintah daerah.

Hasil dari penelitian ini juga menyatakan bahwa SKPD tidak memperkuat pengaruh kekayaan daerah terhadap kinerja penyelenggaraan pemerintah daerah. Sehingga SKPD dianggap kurang mampu dalam melaksanakan tugas dan wewenangnya dalam mengelola 
kekayaan daerah. Seharusnya SKPD dalam mengelola kekayaan daerah atau aset daerah harus memiliki upaya dalam meningkatkan efisiensi, efektifitas dan menciptakan nilai tambah dalam mengelola aset, dan menjadi ini modal awal bagi pemerintah daerah untuk melakukan pengembangan kemampuan keuangannya serta dapat menunjang peran dan fungsi pemerintah daerah sebagai pemberi pelayanan publik kepada masyarakat.

\section{Pengaruh Belanja Modal Terhadap Kinerja Penyelenggaraan Pemerintah Daerah Dengan Kompleksitas Pemerintah Sebagai Variabel Moderasi}

Hipotesi keempat (H4) dalam penelitian ini yaitu kompleksitas pemerintah memperkuat pengaruh belanja modal terhadap kinerja penyelenggaraan pemerintah daerah. Diketahui bahwa dari hasil uji statistik t, interaksi antara belanja modal dengan kompleksitas pemerintah memiliki nlai t hitung sebesar $-1,340$ dengan tingkat signifikan 0,184 besar dari 0,05 . Artinya hipotesis 4 ditolak dengan kata lain interaksi antara belanja modal dengan kompleksitas pemerintah tidak memiliki pengaruh signifikan terhadap kinerja penyelenggaraan pemerintah daerah.

Penyerapan belanja modal dipengaruhi oleh peran dari SKPD sehingga peningkatan kinerja SKPD diharapkan dapat optimal. Jika anggaran belanja publik lebih diorientasikan kepada belanja modal maka akan meningkatkan pelayan kepada masyarakat dan meningkatkan kinerja pemerintah. Belanja modal yang tergolong rendah akan menghambat pembangunan dan pelayanan publik (Aggraeni dan Riduwan, 2014). Dalam penelitian ini juga didapatkan hasil bahwa SKPD tidak memperkuat pengaruh belanja modal terhadap kinerja penyelenggaraan pemerintah daerah. Berarti SKPD di provinsi sumatera barat masih sedikit menggunakan belanja daerah untuk belanja modal sehingga tidak dapat meningkatkan kinerja pemerintahan daerahnya. Untuk itu diharpakan agar pemerintah daerah dapat meningkatkan belanja modal daerah karena belanja modal digunakan pemerintah untuk pelayanan kepada publik. Dan dapat meningkatakan kinerja penyelenggaraan pemerintah daerah.

\section{SIMPULAN, KETERBATASAN DAN SARAN \\ Kesimpulan}

Penelitian ini bertujuan untuk megetahui pengaruh kekayaan daerah dan belanja modal terhadap kinerja penyelenggaraan pemerintah daerah kabupaten/kota provinsi Sumatera Barat dan Untuk mengetahui apakah kompleksitas pemerintah akan memperkuat pengaruh kekayaan daerah dan belanja modal terhadap kinerja penyelenggaraan pemerintah daerah tahun 2013-2017. Hasil penelitian ini menunjukan bahwa kekayaan daerah tidak berpengaruh terhadap kinerja penyelenggaraan pemerintah daerah, dan belanja modal berpengaruh negatif terhadap kinerja penyelenggaraan pemerintah daerah. Kompleksitas pemerintah tidak memoderasi hubungan antara kekayaan daerah dan belanja modal terhadap kinerja penyelenggaraan pemerintah daerah. Hasil penelitian ini juga menunjukan bahwa kompleksitas pemerintah memperlemah hubungan antara kekayaan daerah dan belanja modal terhadap kinerja penyelenggaraan pemerintah daerah.

\section{Keterbatasan}

Penelitian ini telah dirancang dan dilaksanakan dengan sebaik-baiknya, namun peneliti menyadari bahwa masih terdapat keterbatasan dalam penelitian ini yaitu:

1. Penelitian ini hanya dilakukan di kabupaten/kota Provinsi Sumatera Barat dari periode waktu 2013-2017, dan ini menyebabkan hasil penelitian akan berbeda jika dilakukan di daerah lain mengingat perbedaan karakteristik masing-masing wilayah di Indonesia. 
2. Penelitian ini hanya menggunakan data sekunder dari laporan keuangan daerah provinsi sumatera barat dan laporan evaluasi kinerja penyelenggaran pemerintah daerah.

\section{Saran}

Berdasarkan pembahasan dan kesimpulan dalam penelitian ini, maka peneliti mengajukan sran sebagai beriku. Bagi Pemerintah Daerah, diharapkan pemerintah daerah lebih memperhatikan faktor yang bisa meningkatkan kinerja pemerintah daerah, supaya kinerja pemerintah daerah bisa lebih ditingkatkan. Bagi Peneliti Selanjutnya, diharapkan peneliti selanjutnya dapat menambah variabel-variabel dalam penelitian ini untuk menguji pengaruh kinerja penyelenggaraan pemerintah daerah. Dan penelitian selanjutnya untu dapat menambahkan sumber data yang digunakan maupun jangka waktu penelitian agar mendapatkan hasil yang lebih maksimal dan akurat.

\section{DAFTAR PUSTAKA}

Afryansyah, R. D., 2013. Faktor-Faktor yang Mempengaruhi Pengungkapan Informasi Akuntansi di Internet oleh Pemerintah Daerah. Skripsi.

Anggraeni, D. T. \& Riduwan, A., (2014). Faktor-Faktor yang Mempengaruhi Keterandalan Pelaporan Keuangan Pemerintah Daerah (Studi Pada SKPD di Kabupaten Siduarjo). Jurnal Ilmu dan Riset Akuntansi, 3(3).

Ara, S. C., Herwanti, T. \& Putuningsih, E., (2016). Pengaruh Karakteristik Pemda dan Temuan Audit BPK Terhadap Kinerja Pemda Kabupaten di Pulau Sumba. Journal Of Accounting, Finance and Forensic Accounting, 4(1).

Artha, R. D., Basuki, P. \& MT, A., (2015). Pengaruh karakteristik Pemerintah Daerah dan Temuan Audit BPK Terhadap Kinerja Penyelenggaraan Pemerintah Daerah (Studi Empiris pada Pemerintah Kabupaten/Kota di Provinsi NTB). Jurnal Infestasi, 11(2).

Aryani, P. R., 2017. Pengaruh Pertumbuhan Ekonomi, Pendapatan Asli Daerah, dan Dana Alokasi Umum Terhadap Alokasi Anggaran Belanja Modal pada Kabupaten/Kota Provinsi Sumatera Selatan. Universitas Muhamadiyah Palembang.

Brigham, A. F. \& Hauston, J. F., (1999). Manajemen Keuangan. 8 penyunt. Jakarta: Erlangga.

Budianto, W., 2012. Pengaruh Opini, Temuan Audit dan Gender terhadap Kinerja Penyelenggaraan Pemerintah Daerah Kabupaten/Kota di Indonesia Tahun 2008-2010. Skripsi.

Dani, 2019. EKPPD Sumbar 2018 Turun Peringkat, s.1.: HarianHaluan.com.

Harumiati, Y. \& Payamta, (2014). Pengaruh Karakteristik Pemerintah Daerah dan Temuan Audit BPK Terhadap Kinerja Pemerintah Daerah Kabupaten/Kota di Indonesia Tahun Anggaran 2011. Jurnal Akuntansi dan Pendidikan, 3(2).

Hilmi, Z. A. \& Martani, D., (2013). Analisis Faktor-Faktor yang Memperngaruhi Tingkat Pengungkapan Laopran Keuangan Pemerintah Provinsi. Universitas Indonesia.

Jensen , M. C. \& Meckling, W. H., (1976). Theory of the Firm: Managerial Behavior, Agency Costs and Ownership Structure. Journal of Financial Economics, 3(4).

Kadafi, M. E., 2013. Pengaruh Pendapatan Asli Daerah dan Dana Perimbangan Terhadap Belanja Modal. Universitas Widyatama.

Kolinug, M. S., Ilat, V. I. \& Pinatik, S., (2015). Analisis Pengelolaan Aset Tetap Pada Dinas Pendapatan Pengelolaan Keuangan dan Aset Daerah Kota Tomohon. Jurnal EMBA, 3(1). 
Maulana, C., 2015. Pengaruh Karakteristik, Kompleksitas Pemerintahan dan Temuan Audit Terhadap tingkat Pengungkapan Wajib Laporan Keuangan pemerintah Daerah (Studi Empiris Pada Pemerintah Kabupaten/Kota yang Terdapat di Pulau Jawa Tahun 2013). Skripsi.

Mustikarani, W. A. \& Fitriasari, D., (2011). Pengaruh Karakteristik Pemerintah Daerah dan Temuan Audit BPK Terhadap Kinerja Pemerintah Daerah Kabupaten/Kota di Indoneisa Tahun Anggaran 2007. Univesitas Indonesia.

Pamuji, F. A., 2017. Pengaruh Size, PAD dan Kompleksitas Terhadap Kelemahan Pengendalian Intern Pemerintah Daerah. Skripsi.

Peraturan Menteri Dalam Negeri Nomor 73 Tahun 2009 Tentang Tatacara Pelaksanaan Evaluasi Kinerja Penyelenggaraan Pemerintah Daerah

Peraturan Pemerintah Republik Indonesia Nomor 12 Tahun 2019 Tentang Pengeloaan Keuangan Daerah

Peraturan Pemerintah Republik Indonesia Nomor 13 Tahun 2019 Tentang Laporan dan Evaluasi Penyelenggaraan Pemerintah Daerah

Peraturan Pemerintah Republik Indonesia Nomor 71 Tahun 2010 Tentang Standar Akuntansi Pemerintah

Pratama , K. A. D., Werastuti, D. N. S. \& Sujana, E., (2015). Pengaruh Kompleksitas Pemerintah Daerah, Ukuran Pemerintah Daerah, Kekayaan Daerah dan Belanja Daerah Terhadap Pelaporan Keuanagan Pemerintah Daerah (Studi Pada Pemerintah Kabupaten/Kota di Bali Tahun 2010-2013). e-Journal S1 Ak Universitas Pendidikan Ganesha, 3(1).

Puspitasari , T., 2013. Pengaruh Tingkat Pertumbuhan Ekonomi, Pendapatan Asli Daerah (PAD) dan Kompleksitas Pemerintah Daerah (Jumlah SKPD) Terhadap Kelemahan Pengendalian Intern pada Pemerintah Daerah (Studi Empiris Pada Pemerintah Daerah di Indonesia). Skripsi.

Putri, N. K., 2015. Pengaruh Pertumbuhan Ekonomi, Pendapatan Asli Daerah, Ukuran dan Kompleksitas Terhadap Kelemahan Pengendalian Intern Pemerintah Daerah (Studi Empiris Pada Pemerintah Kabupaten/Kota Wilayah Indonesia Bagian Barat Tahun 2012). Skripsi.

Qowi, R. \& Prabowo, T. J. W., (2017). Pengaruh Karakteristik Pemerintah Daerah dan Temuan Pemeriksaan BPK Terhadap Kinerja Pemerintah Daerah Kabupaten/Kota di Indonesia Tahun Anggaran 2012. Diponegoro Journal of Accounting, 6(1).

Sedyaningsih , P. \& Zaky, A., (2013). Pengaruh Karakteristik Pemerintah Daerah Dan Temuan Audit BPK Terhadap Kinerja Penyelenggaraan Pemerintahan Daerah (Studi pada Pemerintah Kabupaten di Sulawesi Selatan Tahun 2009 - 2012). Universitas Brawijaya.

Siddi, P., (2016). Peran Karakteristik Keuangan dan opini Audit dalam Meningkatkan Kinerja Penyelenggaraan Pemerintah Daerah. Jurnal Akuntansi Multiparadigma, 7(3).

Sugiyono. (2008). Metode Penelitian Bisnis. Bandung: Alfabeta.

Susanti, S. \& Pahlevi, H., (2016). Pengaruh Pendapatan Asli Daerah, Dana Alokasi Umum dan Dana Bagi Hasil Terhadap Belanja Modal (Studi Kasus Pada Kabupaten/ Kota Wilayah Aceh). Jurnal ilmiah Mahasisw Ekonomi Akuntansi, 1(1).

Tobu, A. J., 2018. Pengaruh Kareakteristik Pemerintah Daerah dan Temuan Audit BPK Terhadap Kinerja Penyelenggaraan Pemerintah Daerah Kabupaten/Kota (Studi Empiris pada Pemerintah Kabupaten/Kota di Nusa Tenggara Timur Tahun 2013-2015). Skripsi.

Undang-Undang Republik Indonesia Nomor 32 Tahun 2004 Tentang Pemerintah Daerah 
Undang-Undang Republik Indonesia Nomor 33 Tahun 2004 Tentang Perimbangan Keuangan Antara Pemerintah Pusat dan Pemerintah Daerah

Usman, R. \& Misra, F., (2019). Pengaruh Kekayaan Daerah dan Belanja Modal Terhadap Kinerja Penyelanggaraan Pemerintah: Pengujian Legislative Power Sebagai Variabel Pemoderasi. e-Jurnal Akuntansi , 29(2). 